\title{
Canadian Society for Renaissance Studies, Constitution
}

\section{Article I: NAME}

The society shall be called the Canadian Society for Renaissance Studies/ Société canadienne d'études de la Renaissance.

\section{Article II: AIMS AND PURPOSES}

The Canadian Society for Renaissance Studies has for its purpose the promotion and development of Renaissance studies in Canada on a multidisciplinary basis; and that of making available information on research in progress, scholarly meetings and publications in its field both in Canada and abroad.

\section{Article III: MEMBERSHIP}

The following may become members of the Society:

1. Persons involved in teaching of and research in aspects of Renaissance studies, including graduate students.

2. Any person subscribing to the aims and purposes of the Society.

\section{Article IV: THE GENERAL MEETING}

1. There shall be a general meeting of the Society once a year.

2. The general meeting may be called by a decision of the Executive Committee; or on the request of at least $25 \%$ of the membership; but no general meeting may be held unless the entire membership receives six weeks notice at least.

\section{Article V: THE EXECUTIVE COMMITTEE}

The Executive Committee shall have the responsibility of conducting its business, calling the general meeting and carrying out its decisions. 
86 / Renaissance and Reformation

The members of the Executive Committee shall be:

$$
\begin{aligned}
& \text { - the President } \\
& \text { - the Vice-President } \\
& \text { - the Secretary-Treasurer }
\end{aligned}
$$

In addition there will be seven committee members representing as equitably as possible the disciplines contributing to Renaissance studies as well as the different regions of Canada. The term of office will be two years.

\section{Article VI: AMENDMENTS}

The Constitution may be amended either by two-thirds of the members present and voting at a General Meeting provided that no less than six weeks written notice was given to all members; or by a two-thirds majority of the members voting in a postal ballot, provided that the amendment was proposed by the Executive Committee or by any five members of the Society and that no less than six weeks written notice was given to all members. 